\title{
The Relationship between Organizational Citizenship Behavior and Team Performance: The Mediating Effect of Team Conflict
}

\author{
Nishad Nawaz ${ }^{1, *} \&$ Anjali Mary Gomes ${ }^{1}$ \\ ${ }^{1}$ College of Business Administration, Department of Management, Kingdom University, Kingdom of Bahrain \\ *Correspondence: College of Business Administration, Kingdom University, PO Box: 40434, 5th Floor, Bldg. 296, \\ Road 3903/ Al Estiqlal Eve., Block 939, Riffa / Al-Hajiyat, Kingdom of Bahrain. Tel: 973-1330-2820. E-mail: \\ n.navaz@ku.edu.bh
}

Received: October 29, 2017

Accepted: November 28, 2017 Online Published: December 23, 2017

doi:10.5430/mos.v5n1p15

URL: https://doi.org/10.5430/mos.v5n1p15

\begin{abstract}
The present study was conducted in colleges, universities in India to understand the relationship between the team performance, organizational citizenship behavior and team conflict. The data has been collected through questionnaire and analyzed data to know the team conflict mediation effect on relationship conflict, task conflict, team performance and organizational citizenship behavior. The study consist of 204 team members which participated from 25 different colleges and universities and the data analysis was performed through SPSS 22 version used for hierarchical regression to get desire results. The detailed analysis was performed and discussed in detail.
\end{abstract}

Keywords: team conflict; relationship conflict; task conflict; team performance; OCB

Paper type: Research Paper

\section{Introduction}

After 1947, there has been tremendous development in the field of higher education in India, universities and colleges have come gradually huge and socialized in the process of internationalization, in addition, the job market increased the demand for knowledge, skills and abilities to grasp these demands. In the present education environment required efficient and effective management teams to handle the management complexity.

According to the theory of upper echelons, scholars have been found that demographic functions such as structure of the team and interpersonal relationship are most important backgrounds in the concept of team conflict, (Knight et al., 1999),(Talaulicar, Grundei, \& Werder, 2005), (P.R.China., 2013). In the enhancement of research for the team performance the variable of team conflict is a explanatory variable. (Pelled, 1996). In addition to the that, in the previous studies has been concentrated on the role of performance and ignored extra-role performance. It is obvious is that organizational citizenship behavior (OCB) is heavily used as the indicator in the extra-role performance, there are very less stayed theoretical analysis and empirical studies on internal mechanism between team conflict and not many studies are done in this direction.

(Barua, 2012) pointed out that team functioning and empowerment of team dimensions were measured by following factors such as cohesion, confrontation, collaboration, task clarity, autonomy, support and accountability. (Ajay Kr Singh, 2005) the study has been conducted in 11 different industries and 126 executive level employees were considered for the analysis and concluded that trust, cooperation, involvement and coordination are some of the most significant elements for better team work. The study was based on software development teams, these teams team climate play main role in team performance, further more virtual characteristics negatively affected the team climate; therefore the study had attention towards virtual characteristics of software development teams.(Ganesh \& Gupta, 2006). The study conducted on team effectiveness of an Indian garments company by having total number of respondents 100, in detail 20 responses from each of the 5 departments and found that utilization of employee and employee participation in decision making process are most important factors in team to be effective (Tamilmani, Ravichandran, Sandeepojha, 2005) and leader productivity values also keep track of effective teamwork (Bhatnagar \& Tjosvold, 2012). The study conducted in Indian public and private service and manufacturing organizations and 
found that trust, communication and cooperation will increase efficiency and improve the team performance(Verma, Rangnekar, \& Barua, 2011).

Research in organizational citizenship behavior (OCB) is still in premature stage, it is very unique to transmission mechanism that the team conflict has on organizational citizen behavior. The present study has an attempt to make up for the lack mentioned above, the study explores the inter mechanism between team conflict and OCB by drawing on organizational performance in the context of India. The present study will help us to understand the relationship between the $\mathrm{OCB}$, team performance and team conflict. In addition to that it will facilitate some insights to the management team in the universities and colleges in India.

\section{Literature Review and Hypothesis Development}

\subsection{Team Performance and Organizational Citizenship Behavior}

(Organ, D. W. 1988) expressed his opinion on OCB, it is not only adding to performance and it will also influence how managers evaluate employees. According to (Organ, Podsakoff, Philip \& Dennis, 1990) is composed of five factors such as civil virtue, courtesy, altruism, conscientiousness and altruism and also proposed altruistic behavior \& polite model belongs to the OCB to the individual, sportsmanship, civil virtue and belong to OCB. On the other hand (Smith, Organ, \& Near, 1983) summarized the foreign OCB into seven parts such as helping behavior, sportsmanship, organizational loyalty, organizational compliance of individual initiative, civic virtue and self-development, in addition the (Organ, D. W. 1988) organizational citizenship behavior continuously improves organizational performance. After that, many authors also constructed the same opinion on OCB that can enhance the organizational performance. Another valuable contribution from (Podsakoff, MacKenzie, Paine, \& Bachrach, 2000) explained that OCB effects on organizational performance into seven areas of the organization such as (i) improves the effectiveness of peers \& managers;(ii) it will release the resources for more productive activities; (iii) keep low ratio of scarce resources within the organization for normal operation; (iv) facilitate the coordination among the groups and work groups; (v) organization obtain abilities to attract and retain the skills of human resources; (vi) organization will become stabilized and (vii) organizations acts as per the change management.

Organ once again pointed out that research would focus on the mediating variables in the study of organizational citizenship behavior in near future. In the past 20 years, there has been enough evidence to show that organizational performance is an important variable in the context of organizational citizenship behavior. OCB directly have an effect on team performance, there are a number of rationales given for, why OCB may relate positively to work group or organization effectiveness (Podsakoff et al., 2000).

\subsection{Organizational Citizenship Behavior and Team Conflict}

Bateman and Organ has introduced the OCB in the year 1983 and expressed that individual behavior is not flexible directly or explicitly recognized by the formal reward system and it will energized in the formal reward system and that will promote the efficient functioning of the organization.

From two decades organizational citizenship is seen as a research hotspot in the discipline of applied psychology and organizational behavior, on the one hand OCB itself acts as a relationship performance; On the other side, it can serve to lubricate the organization, reduce friction and organization transaction cost to improve organizational performance (Organ, D. W. 1988). In the organization OCB is not the behavior required by role and it will plays an efficient role in the organizational operation. In opinion of (Jones, 2013) trusted that organizational citizenship behavior was affected by background factors. The concept of conflict not only exists in all the levels of human society, but is also inevitable. From the past decades team conflict has been divided into task conflict and relationship conflict by nature (Jehn, 2001).

\section{Relationship Conflict}

The concept of relationship conflict explain the interpersonal incompatibilities among the team members, which typically includes animosity, tension, and annoyance among members within a group.(Jehn, 1995). The relationship conflict effect with negative emotions it will produce cognition of the team members, interfere will occur on duties and responsibilities, this may low-grade the team members' satisfaction. As per the (Vianen, Annelies, 2000) avoiding relationship enhance the team functions and team behaviors, expressing the opinions and organizational commitment. In relationship conflict compels team members to mainly focus on time and energy of individuals rather than the team performance, and leads to stress \& anxiety results in upgrading mutual antagonism and makes team members unwilling to put extra efforts and resources into resolving and assisting colleagues and 
maintain interpersonal harmony beyond the requirements of their own responsibilities and roles. Based on the above analysis, we hypothesize.

\section{H 1: Relationship conflict has a positive effect on organizational citizenship behavior.}

\section{Task Conflict}

In the context of disputes of task in the pursuit of goals of the organization, which includes views, ideas and their opinions. When handing uncertain issues which require huge number of data and information, a small amount of task conflict could cause the team think and enlarge the analysis and solution, so that the team can be more effective, efficient, flexible and innovative thinking to resolve the issues.

On the other side, from the opinion of (Jehn, 1995) task conflict would lead to internal anxiety, anger and even decreasing the willingness to work together. Therefore, it is very difficult to adopt tasks and works in the organization. For this reason, there is a need to moderate task conflict to avoid intensifying the conflict, but also helps team members to collect sufficient information and data. This will be extent cognitive conflict and it will develop the senses of responsibility and irrational senses of belonging. The team members when they identify their interest, it is closely associated; they will express organizational citizenship behavior without being important. Based on above statement and analysis, we make the following assumption:

\section{H 2: Task relationship has a positive effect on organizational citizenship behavior.}

\subsection{The Mediating Effect of Team Conflict}

Apart from the above discussion, current study argument is that team conflict will mediate the relationship between the organizational citizenship behavior and organizational performance. (Hackman \& Morris, 1975) noted that a team's task design is one of the most powerful part to determinants of what constitutes an effective process for promoting performance. Our model of team conflict management deviates from these models in that it also considers the moderating effect of organizational performance. The models of input-process-output expressed that task interdependence for team conflict, empowers team members to resolve conflicts efficiently in order to elevate their performance (West, 2002).

Based on the above description, the following hypotheses has been designed

\section{H 3 Relation conflict has a positive effect on team performance}

\section{H 4 Task conflict has a positive effect on team performance}

H 5 Team conflict plays a mediating role in relationship between task conflict and organizational citizenship behavior.

H 6 Team conflict plays a mediating role in relationship between relationship conflict and organizational citizenship behavior.

H 7 Team conflict plays a mediating role in relationship between team performance and organizational citizenship behavior.

\section{Research Methods}

\subsection{Data Collection and Sample}

The present study offering them to participate in the web-based survey, the study included 204 team members from 25 colleges and universities from India. 250 questionnaires were sent via email and 210 questionnaires were received, the recovery rate is 84 percent, after scrutinize, the final sample included 204 questionnaires that was fit for analysis, the effective rate is 97 percent.

\subsection{Design of the Questionnaire}

Organizational citizenship behavior was measured with five items, team performance was measured with three items, team conflict measured with four items, relationship conflict measured with four items and task conflict measured with four items. The previous research studies has shown that individual's demographic factors, such as age, qualification, number of years in current profession, number of years in current job, number of years stayed in the same team and team size would affect the organizational citizenship behavior. The study has been considered demographic factors (6 variables) as control variables. 


\subsection{Statistical Tools Used}

The data further analyzed through SPSS 22 version used for hierarchical regression testing and the results has been drawn.

\subsection{Measures}

The Likert scale of items in our study were ( $1=$ never, $5=$ always $)$ for team conflict and task conflict and relationship conflict and for team performance $\&$ organizational citizenship behavior $(1=$ strongly disagree, $5=$ strongly agree), (Van alphen, Halfens, Hasman, \& Imbos, 1994) team conflict with 4 items scale $(\alpha=0.74)$, task conflict with 4 items scale $(\alpha=0.79)$, relationship conflict with 4 items scale $(\alpha=0.81)$, organizational citizenship behavior with 5 items scale $(\alpha=0.90)$ and team performance with 3 items scale $(\alpha=0.91)$.

Table 1. Source of Factors Selected

\begin{tabular}{rr}
\hline Variable & Source of factors selected \\
Team Conflict & $\begin{array}{r}\text { Source (s) } \\
\text { (Bai, Han, \& Harms, 2016),(Somech, Desivilya, \& Lidogoster, } \\
2009) \&(\text { Simonss, T. L. Peterson, 1998) Simonss, T. L. Peterson } \\
\text { 1998) } \\
\text { Task Conflict }\end{array}$ \\
Relationship conflict & (Simons \& Peterson, 1998)(De Dreu \& Weingart, 2003) \\
Team Performance & (Jafari \& Bidarian, 2012) \\
(P.R.China., 2013)
\end{tabular}

\section{Results}

4.1 Descriptive Statistics and Reliability Coefficient

Table 2. Descriptive Statistics and Reliability Coefficient

\begin{tabular}{rrrrr}
\hline S.No & Variable & Mean & SD & Cronbach's Alpha $(\alpha)$ \\
\hline 1 & Gender & 1.26 & 0.44 & \\
2 & Qualification & 2.29 & 0.86 & \\
3 & NYCJ & 2.29 & 1.51 & \\
4 & NYCP & 3.25 & 2.17 & \\
5 & NYSST & 1.80 & 1.50 & 0.74 \\
6 & Team size & 1.98 & 0.57 & 0.79 \\
7 & Team conflict & 11.75 & 2.98 & 0.81 \\
8 & Task conflict & 12.61 & 3.36 & 0.91 \\
9 & Relationship conflict & 11.26 & 3.43 & 0.90 \\
10 & Team performance & 10.07 & 2.77 & \\
11 & OCB & 16.12 & 4.27 & \\
\hline
\end{tabular}

Note: N=204, OCB: organizational citizenship behavior, NYCJ: Number of years in current job, NYCP: Number of years in profession, NYSST: Number of years stayed in the same Team, SD: Standard deviation.

The Table 2 shows all major variables are significantly correlated $(\mathrm{p}<0.1)$ and $(\mathrm{p}<0.10)$, among which Team conflict and Task conflict $(\mathrm{r}=0.799)(\mathrm{p}<0.05)$, Team conflict and Relationship conflict $(\mathrm{r}=0.486)(\mathrm{p}<0.01)$ Team conflict and Team performance $(\mathrm{r}=601)$, organizational citizenship behavior and Team conflict $(\mathrm{r}=-0.365)$, is negatively 
correlated, Task conflict and Relationship conflict $(\mathrm{r}=0.489)$, Task conflict and Team performance $(\mathrm{r}=0.533)$, Team conflict and organizational citizenship behavior $(\mathrm{r}=0.575)$, Relationship conflict and Team performance $(\mathrm{r}=0.129)$, Relationship conflict and organizational citizenship behavior $(\mathrm{r}=0.136)$ and Team performance and organizational citizenship behavior $(\mathrm{r}=0.858)$, except Team conflict and organizational citizenship behavior, remaining all significantly positively correlated. In addition to that (Peterson, 1994) suggested the following rule of thumb " $>$ than equal to 0.9 Excellent, $>$ than equal to $0.8 \mathrm{Good}$, $>$ than equal to 0.7 Acceptable $>$ than equal to 0.6 Questionable, $>$ than equal to 0.5 poor and < than equal to 0.5 unacceptable, in the present study the values are between 0.74 to 0.91 so there is vailed reliability coefficient.

\subsection{Hierarchical Regression Testing and Hypotheses Testing}

According to (Namazi \& Namazi, 2016) \& (Baron \& Kenny, 1986) expressed that four conditions has to be significant. In first dependent variable and independent variable should be correlated, after that independent and mediating variable must be correlated, third dependent variable and mediate variable must be correlated and finally at the time of mediate variable included on dependent variable should disappear. Therefore, the present study has implemented the hierarchical regression method for the present data.

Table 3. Means, SD and Correlations of the Measured Variables

\begin{tabular}{rrrrrrrr}
\hline & & Mean & SD & TC & TAC & RC & TP \\
\hline 1 & Team conflict & 11.75 & 2.98 & & & & \\
2 & Task conflict & 12.61 & 3.36 & $0.466^{* *}$ & & & \\
3 & Relationship conflict & 11.26 & 3.43 & $0.143^{*}$ & $0.402^{* *}$ & & \\
4 & Team performance & 10.07 & 2.77 & $0.405^{* *}$ & $0.171^{* *}$ & $0.524^{* *}$ & \\
5 & OCB & 16.12 & 4.27 & $-0.251^{* *}$ & $0.143^{* *}$ & $0.587^{* *}$ & $0.871^{* *}$ \\
\hline
\end{tabular}

Note: TC: Team conflict, TAC: Task conflict, RC: Relationship conflict, TP: Team performance, $* * p<0.01$ and * $\mathbf{p}<\mathbf{0 . 0 5}$

Can be observed in the above Table 3 the Relationship conflict has a positive effect on the organizational citizenship behavior $(\beta=.234 * *)$, Thus, the $\mathrm{H} 1$ has been confirmed. In the next step Task conflict has been established with positive effect on the organizational citizenship behavior $(\beta=.624 *)$, thus $\mathrm{H} 2$ has been found. In the next step team performance has been added in the model which shows the positive impact of Relationship conflict on the team performance $(\beta=.816 * *)$, thus, the $\mathrm{H} 3$ has been established and the there is a positive effect of Task conflict on the Team performance $(\beta=.624 * *)$, Thus, the $\mathrm{H} 4$ has been accepted.

As per the (Durbin \& Watson, 1951) stated that in calculation of the hierarchical regression Durban Waston values should be in between 0 to $<2$ is the positive autocorrelation, the present study reached the value of 1.910 , so it is indication that there is positive correlation between the variables.

From the Table 4 explains the detailed analysis of the team conflict mediation, for reaching to the analysis the researchers has been considered to prove the hypothesis, in the first the Demographical variables has been introduced by keep the OCB as dependent variable, in the next step inserted the values Number of years stayed in the same team and team size, in the third step team conflict values has been introduced, Fourth relationship conflict values has been added, Fifth the task conflict variables has been into the hierarchical regression and finally team performance variables has been implemented to calculate the mediation effect of the team conflict on the organization performance and organizational behavior citizenship.

From the data of the Table 4, from the step 4 we can spot the value of the regression of the task conflict effect on the organizational behavior citizenship is significant (thus, it is established the $\mathrm{H} 5$.

From the step 6 regression model the team conflict negatively mediating on the organizational citizenship and relationship conflict (while keeping step 5 and step six there is positive effect on the organizational citizenship behavior, Therefore, $\mathrm{H} 6$ is accepted.

In the step of the 6 , the organizational performance is added into the model and it is showing positive (significant relationship on the organizational citizenship behavior. Thus $\mathrm{H} 7$ has been established. In addition to that the value of coefficient decreased has been felt down, when comparing to the step 5 to step 6 . 
Table 4. Result of Hierarchical Regression Team Conflict on Team Performance on Organizational Citizenship Behavior

\begin{tabular}{rrrrrrr}
\hline Variables & Step 1 & Step 2 & Step 3 & Step 4 & Step 5 & Step 6 \\
Gender & -.406 & -.437 & -.499 & -.678 & -.468 & -.353 \\
Qualification & .088 & .122 & .134 & .766 & .192 & .180 \\
Number of years in current job & -.137 & -134 & -.148 & -.154 & .018 & .028 \\
Number of years in profession & .033 & -.010 & .015 & -.001 & .004 & -.066 \\
Team size & & .027 & .068 & .071 & .085 & .027 \\
Team conflict & & & $-.158^{*}$ & $-.289^{*}$ & $-.204^{*}$ & -013 \\
Number of years stayed in the same Team & & .067 & 0.678 & .050 & .045 & -.052 \\
Relationship conflict & & & & $.337^{* *}$ & .003 & .042 \\
Task conflict & & & & & $.630^{* *}$ & $.164^{*}$ \\
Team Performance & & & & & & $.809^{*}$ \\
$\mathrm{R}^{2}$ & .090 & .103 & .122 & .186 & .434 & .832 \\
$\Delta \mathrm{R}^{2}$ & .090 & .013 & .019 & .064 & .248 & .398 \\
$\mathrm{~F}$ & 4.914 & $3.777^{* *}$ & $3.882^{* *}$ & $5.576^{* * *}$ & $16.506^{* * *}$ & $15.590^{* * *}$ \\
\hline
\end{tabular}

Note: ${ }^{*} \mathrm{p}<0.05 ; * * \mathrm{p}<0.01 ; * * * \mathrm{p}<0.001$

Note 2: TP: Team Performance, OCB : Organizational behavior citizenship behavior, TAC: Team conflict.

\section{Discussions}

The present study has provided deepen understanding of team conflict, task conflict, relationship conflict, team performance and organizational citizenship behavior in the context of Indian colleges and universities, it can extend present research and organizational theories. From the analysis there are many finding has been drawn the team conflict negative effect on the organizational performance and organizational citizenship behavior.

In the relationship conflict has a positive effect on the team performance, in respect of organizational citizenship behavior there is very low impact. The team conflict mediation also shown as a low effect on the relationship conflict. Based on this, there is conflict relationship between the relationship conflict and organization citizenship behavior. When the conflict appears in a team, a great deal of time, resources and energy is wasted in managing or coordinating interpersonal relations. Team tensions will enhance and produce low cognitive abilities and disturbance in the relations among the team members. It will directly effect on the performance of the members in the organizations; these low rates of performance will impact the members and decrease the organizational citizenship behavior.

Furthermore, task conflict has significant positive impact on the team performance and organizational citizenship behavior. The team conflict is mediating between the task conflict and organizational citizenship behavior; there is certain level of contribution in the organizational citizenship behavior, it stimulates the team members to think diversely from the team members and it will enrich the knowledge exchange, reviews of tasks and innovative ideas and thoughts of the team will be improved.

In addition to that the mediation of the team conflict is mediating between the organizational performance and organizational citizenship behavior and it has positive effect on both. The team members energized with the professional development programs, knowledge exchange and display positive attitudes and emotions to enhance the job satisfaction. The team members consider themselves to be treated unbiased and fairly, they may be ready to do anything and they produce more than the organizations expectations.

\subsection{Applied Implication}

At present management team members belongs to either government administration or other administration in the colleges and universities in India. There is a lack of mechanism, the team conflict is one of the important concern in the management team. There is a team conflict influence on organizational citizenship behavior through the team 
performance.

The present study keeping some suggestions for the purpose of achieving effective and efficient operation process in the colleges and universities, at first organizations have to encourage knowledge sharing and knowledge collaboration platforms in their organizational structure of the management team and it should have inclusion of the professors in decision making process. In the next step the organizations have to adopt mechanism of team performance indicators, it should boost the high level of organizational citizenship behavior. Finally, the administrators, leaders of the organizations should implement scientific methods to respond to various conflicts.

\section{Limitations and Future Research Avenues}

The study has drawn some conclusion through the empirical study \& made some contributions to the present theory and practice. The study clamps some of the limitations. The study was done with small sample size; it can be extended by having more sample size. Second the researcher has taken some of the colleges and universities in India; it can be extended by having large number of colleges and universities. Third, there is another scope for further studies it can be done between colleges, universities in between state universities and central universities, in addition to that there is additional scope for further studies to make comparative studies between state universities. And finally, the present study has taken team conflict has a mediating variable; it can be possible in future studies by having task conflict and relationship conflict as mediating variable.

\section{References}

Ajay Kr Singh, A. (2005). The spirit of teamwork An empirical study of selected organization. Delhi Business Review, 6(2), 1-18.

Bai, Y., Han, G. H., \& Harms, P. D. (2016). Team Conflict Mediates the Effects of Organizational Politics on Employee Performance: A Cross-Level Analysis in China. Journal of Business Ethics, 139(1), 95-109. https://doi.org/10.1007/s10551-015-2604-6

Baron, R. M., \& Kenny, D. A. (1986). The Moderator-Mediator Variable Distinction in Social The Moderator-Mediator Variable Distinction in Social Psychological Research: Conceptual, Strategic, and Statistical Considerations. Journal of Personality and Social Psychology, 51(6), 1173-1182. https://doi.org/10.1037/0022-3514.51.6.1173

Barua, M. K. (2012). Team effectivness in Indian organization. Delhi Business Review, 13(2), 43-54.

Bhatnagar, D., \& Tjosvold, D. (2012). Leader values for constructive controversy and team effectiveness in India. International Journal of Human Resource Management, 23(1), 109-125. https://doi.org/10.1080/09585192.2011.610961

De Dreu, C. K. W., \& Weingart, L. R. (2003). Task versus relationship conflict, team performance, and team member satisfaction: A meta-analysis. Journal of Applied Psychology, 88(4), 741-749. https://doi.org/10.1037/0021-9010.88.4.741

Durbin, J., \& Watson, G. S. (1951). Testing for Serial Correlation in Least Sqares Regression. II. Biometrika, 38(1), 159-177. https://doi.org/10.1093/biomet/72.2.241

Ganesh, M. P., \& Gupta, M. (2006). Study of Virtualness, Task Interdependence, Extra-Role Performance and Team Climate in Indian Software Development Teams. In Proceedings of the 20th Australian New Zealand Academy of Management (ANZAM) Conference on Management, Pragmatism, Philosophy, Priorities, Central Queensland University, Rockhampton (pp. 1-19).

Hackman, R., \& Morris, C. (1975). Group tasks, group interaction process, and group performance effectiveness: A review and proposed integration. Advances in Experimental Social Psychology, 8(C), 45-99. https://doi.org/10.1016/S0065-2601(08)60248-8

Jafari, P., \& Bidarian, S. (2012). The Relationship Between Organizational Justice and Organizational Citizenship Behavior. Procedia - Social and Behavioral Sciences, 47, 1815-1820. https://doi.org/10.1016/j.sbspro.2012.06.905

Jehn, K. A. (1995). A Multimethod Examination of the Benefits and Detriments of Intragroup Conflict. Administrative Science Quarterly, 40(2), 256-282. https://doi.org/10.2307/2393638 
Jehn, K. A. (2001). the Dynamic Nature of Conelict: a Longitudinal Study of Intragroup Conflict and Group Performance. ${ }^{\circledR}$ Academy of Management Journal, 44(2), 238-251. https://doi.org/10.2307/3069453

Jones, G. (2013). A Study on the Relationship between Management Team Conflict and Organizational Citizenship Behavior in Colleges and Universities: The Mediating Effect of Organizational Justice. International Conference on Management Science \& Engineering (20th), 13, 1427-1432.

Knight, D., Pearce, C. L., Smith, K. G., Olian, J. D., Sims, H. P., Smith, K. A., \& Flood, P. (1999). Top management team diversity, group process, and strategic consensus. Strategic Management Journal, 20(5), 445-465. https://doi.org/10.1002/(SICI)1097-0266(199905)20:5<445::AID-SMJ27>3.0.CO;2-V

Namazi, M., \& Namazi, N.-R. (2016). Conceptual Analysis of Moderator and Mediator Variables in Business Research. Procedia Economics and Finance, 36(16), 540-554. https://doi.org/10.1016/S2212-5671(16)30064-8

Organ, Podsakoff, Philip, \& Dennis. (1990). Accounting for Organizational Citizenship Behavior: Leader Fairness and Task Scope versus Satisfaction. Journal of Management, 16(4), 705-721. https://doi.org/10.1177/014920639001600404

P.R.China., H. (2013). A Study on the Relationship between Management Team Conflict and Organizational Citizenship Behavior in Colleges and Universities: The Mediating Effect of Organizational Justice. International Conference on Management Science \& Engineering, 7(13), 1427-1432.

Pelled, L. H. (1996). Demographic Diversity, Conflict, and Work Group Outcomes: An Intervening Process Theory. Organization Science, 7(6), 615-631. https://doi.org/10.1287/orsc.7.6.615

Peterson, R. A. (1994). A Meta-Analysis of Cronbach's Coefficient Alpha. Journal of Consumer Research, 21(2), 381-391. https://doi.org/10.1086/209405

Podsakoff, P. M., MacKenzie, S. B., Paine, J. B., \& Bachrach, D. G. (2000). Organizational Citizenship Behaviors: A Critical Review of the Theoretical and Empirical Literature and Suggestions for Future Research. Journal of Management, 26(3), 513-563. https://doi.org/10.1177/014920630002600307

Simons, T. L., \& Peterson, R. S. (1998). Task Conflict and Relationship Conflict in Top Management Teams:The Pivotal Role of Intragroup Trust. Academy of Management Proceedings, 1998(1), 1-8. https://doi.org/10.5465/APBPP.1998.27667017

Simonss, T. L., \& Peterson, R. S. (1998). Task Conflict snd Relationship Conflict in Top Management Teams:The Pivotal Role of Intragroup Trust. Academy of Management Proceedings, 1998(1), A1-A8. https://doi.org/10.5465/APBPP.1998.27667017

Smith, C. A., Organ, D. W., \& Near, J. P. (1983). Organizational citizenship behavior: Its nature and antecedents. Journal of Applied Psychology, 68(4), 653-663. https://doi.org/10.1037/0021-9010.68.4.653

Somech, A., Desivilya, H. S., \& Lidogoster, H. (2009). Team conflict management and team effectiveness: The effects of task interdependence and team identification. Journal of Organizational Behavior, 30(3), 359-378. https://doi.org/10.1002/job.537

Talaulicar, T., Grundei, J., \& Werder, A. V. (2005). Strategic decision making in start-ups: The effect of top management team organization and processes on speed and comprehensiveness. Journal of Business Venturing, 20(4), 519-541. https://doi.org/10.1016/j.jbusvent.2004.02.001

Tamilmani, Ravichandran, \& Sandeepojha, A. K. (2005). Evaluation of Team Effectiveness. SSRN Electronic Journal, 1-4.

Van alphen, A., Halfens, R., Hasman, A., \& Imbos, T. (1994). Likert or Rasch? Nothing is more applicable than good theory. Journal of Advanced Nursing, 20(1), 196-201. https://doi.org/10.1046/j.1365-2648.1994.20010196.x

Verma, N., Rangnekar, S., \& Barua, M. K. (2011). Impact of Need Pattern on Team Effectiveness : A Study in Indian Perspective. Journal of Management \& Public Policy, 3(1), 23-35.

Vianen, Annelies, E. (2000). Person-Organization Fit: the Match Between Newcomers' and Recruiters' Preferences for Organizational Cultures. Personnel Psychology, $53(1), \quad 113-149$. https://doi.org/10.1111/j.1744-6570.2000.tb00196.x

West, M. (2002). Sparkling fountains or stanant ponds: An integrative model of creativity and innovation implementation in work groups. Applied Psychology: An International Review, 51(3), 355-424. 